\title{
Penile Fracture and False Penile Fracture: Is The Surgical Treatment Always Necessary?
}

\author{
Haci Polat ${ }^{1}$ Ugur Lok L Umut Gulacti $^{2}$
}

\begin{abstract}
Objective: Penile fracture and "false penile fracture" are two emergent cases with similar clinical features. The differential diagnosis is important to avoid unnecessary surgery. In this study, we focused on understanding to distinguish between penile fracture and "false penile fracture".
\end{abstract}

Methods: We retrospectively examined the clinicopathological features of 27 patients with a diagnosis of penile fracture and "false penile fracture" between June 2012 and June 2015.

Results: Twenty-two patients were diagnosed with penile fracture with 20 out of 22 patients undergoing surgical treatment with no complications. Conservative treatment was applied to two patients, however one patient developed erectile dysfunction. Five patients were diagnosed with "false penile fracture". Two patients underwent surgical treatment and three patients underwent conservative treatment. There were no complications in the five patients.

Conclusion: We suggest that surgical treatment is needed for the treatment of penile fracture. However, there is no need to surgical exploration for treatment of "false penile fracture". Conservative treatment is sufficient for "false penile fracture". J Clin Exp Invest 2016; 7 (2): 174-177

Key words: penile disease, penile fracture, complications, erectile dysfunction, urology, emergency

\section{Penil Fraktür ve Yalancı Penil Fraktür: Cerrahi Tedavi Her Zaman Gerekli midir?}

\section{ÖZET}

Amaç: Penil fraktür ve "yalancı penil fraktür" benzer klinik özelliklere sahip iki acil patolojidir. Gereksiz cerrahiden kaçınmak için ayırıcı tanısı önemlidir. Biz bu çalışmada penil fraktür ile "yalancı penil fraktür" arasındaki ayrımı anlamaya odaklandık.

Yöntemler: Haziran 2012 ile Haziran 2015 arasında penil fraktür ve "yalancı penil fraktür" tanılarıyla takip edilen 27 hastanın verilerini geriye dönük olarak inceledik.

Bulgular: Penil fraktür tanısı ile takip edilen 22 hastanın 20'sine cerrahi tedavi uygulandı ve bu hastalarda komplikasyon gelişmedi. Konservatif tedavi uygulanan iki hastanın birinde komplikasyon olarak erektil disfonksiyon gelişti. "Yalancı penil fraktür" nedeniyle beş hasta takip edildi. İki hastaya cerrahi tedavi ve üç hastaya konservatif tedavi uygulandı. Bu beş hastanın hiçbirinde komplikasyon gelişmedi.

Sonuç: Penil fraktür tedavisi için cerrahi tedavinin mutlak gerekli olduğunu düşünüyoruz. Fakat, bize göre "yalancı penil fraktür" için cerrahi tedaviye gerek yoktur. "Yalancı penil fraktür" tedavisinde konservatif yaklaşım yeterlidir.

Anahtar kelimeler: penil fraktür, komplikasyon, erektil disfonksiyon, üroloji, acil

\section{INTRODUCTION}

Penile fracture is a relatively common clinical condition, caused by the rupture of tunica albuginea of corpora cavernosa following a blunt trauma to the erect penis. The rupture of penile vessels i.e. superficial dorsal vein, deep dorsal vein and dorsal artery may resemble a penile fracture without the tunical tear [16]. Those vascular injuries can be called "false penile fracture" which should be treated a different way. To our knowledge, there are only a few cases reporting on the penile vascular injuries mimicking penile frac-

${ }^{1}$ Adiyaman University, Faculty of Medicine, Department of Urology, Adiyaman, Turkey

${ }^{2}$ Adiyaman University, Faculty of Medicine, Department of Emergency Medicine, Adiyaman, Turkey

Correspondence: Haci Polat,

Adiyaman University, Faculty of Medicine, Department of Urology, Adiyaman, Turkey Email: dr.polat@hotmail.com Received: 14.03.2016, Accepted: 26.04.2016

Copyright @ JCEI / Journal of Clinical and Experimental Investigations 2016, All rights reserved 
ture. Surgery is usually performed for the treatment of the rupture of penile vessels [1-6]. We believe that surgical exploration is not mandatory for treatment of "false penile fracture".

Our objective in this study is to report the clinicopathologic characteristics and treatment options i.e. surgical or nonsurgical treatment of penile fracture and "false penile fracture" and to evaluate its association with sexual and voiding functions.

\section{METHODS}

\section{Study design and setting}

We conducted a retrospective chart review on twentyseven patients diagnosed with penile fracture and/or "false penile fracture" that had a follow up visit at the urology and/or emergency department (ED) between June 2012 and June 2015. Informed consent from patients was obtained.

\section{Study population}

Patients' detailed medical history, clinical presentation, physical findings, diagnosis, operative and nonoperative treatment and postoperative details were obtained from hospital information system and patient physical examination record in the ED and urology recorded. The patients were not subjected to any imaging procedure or other examination except routine preoperative tests. Distinction of penile fracture and "false penile fracture" was made according to the following criteria. The presence of at least one of following criteria was considered as penile fracture; specifying a "snapping or cracking" sound, painful and rapid penile detumescence, swelling and hematoma exceeding the dorsal penile, penile deformity, and/or urethral injury.

The ruptured tunica was promptly repaired on the day of presentation or within the next 24 hours.
Surgical repair was summarized as follows; degloving circumferential incision of the penile skin and dartos fascia were performed. The hematoma was evacuated. Following identification of the site and number of tunical defect, it was closured by 2-0 vicryl absorbable sutures in continuous manner.

Patients with follow-up period of less than one year or irregular were excluded from study.

\section{Statistical analysis}

The continuous variables are expressed as the mean \pm standard deviation (SD). The categorical data are expressed as percentages. Chi-square tests were used for the analyses of categorical variables. The data were analyzed with SPSS v. 17.0.

\section{RESULTS}

The treatment modalities applied to patients according to the initially diagnosis and complications encountered is shown in the Table 1.

Twenty-seven patients were followed with initial diagnosis of penile fracture and false penile fracture. Twenty-two patients were diagnosed with penile fracture and their mean age was 35 years (range, 22 to 56). Twenty patients had surgical treatment (Figure 1) with no complications. Conservative treatment was applied to two patients within admission to our hospital after 48 hours. One patient developed erectile dysfunction. Five patients were diagnosed with "false penile fracture" and their mean age was 33 years (range, 25 to 42). Surgical treatment was performed in two patients and three patients underwent conservative treatment. None of the patients had complications (Figure 2). Furthermore, none of the patients had a suspicion of urethral injury (urethral bleeding or urinary retention).
Table 1. The treatment modalities applied to patients according to the initially diagnosis and complications developed

\begin{tabular}{lcccc}
\hline Diagnosis & Treatment modalities & $\mathbf{N}(\%)$ & \multicolumn{2}{c}{ Complications, N (\%) } \\
\hline Penile fracture & & Erectile dysfunction & Others \\
& & $22(100)$ & & - \\
& Conservative & $2(9)$ & $1(50)$ & - \\
\hline False penile fracture & Surgical & $20(91)$ & - & - \\
& & $5(100)$ & - & - \\
& Conservative & $3(60)$ & - & - \\
\hline
\end{tabular}




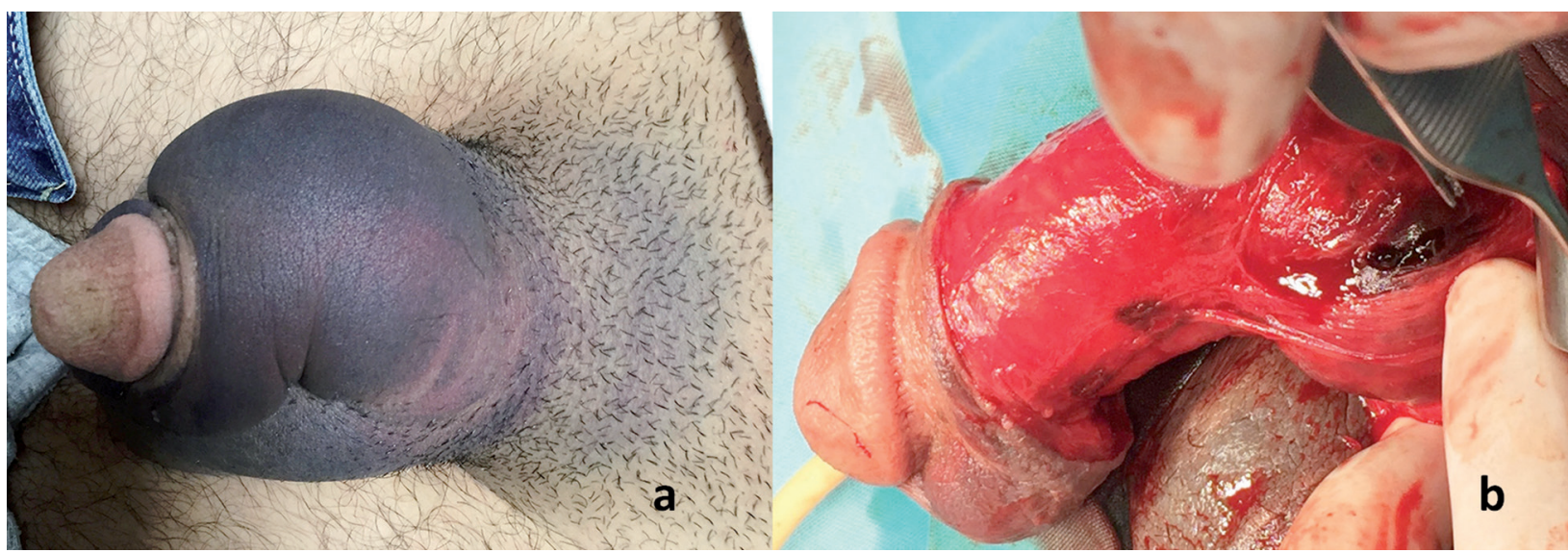

Figure 1. Preoperative (a) and perioperative (b) images of a patient with penile fracture

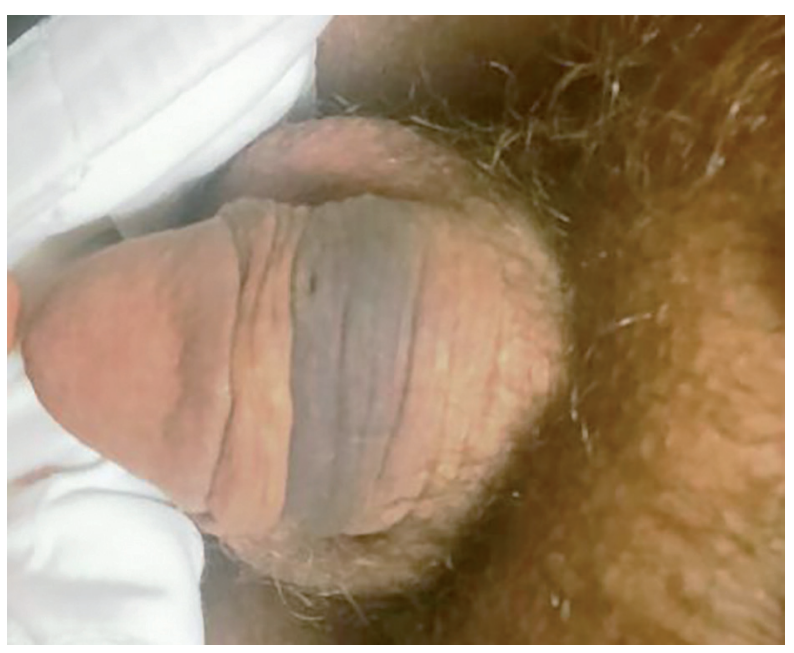

Figure 2. Image of a patient evaluated as "false penile fracture"

\section{DISCUSSION}

One of the wonderful events occur in human body is penile erection. The penis which is one of the soft tissues in the body generates a bone-like rigidity during erection. The corpora cavernosa of the penis becomes engorged with blood and the tunica albuginea thins from $2 \mathrm{~mm}$ to $0.25-0.5 \mathrm{~mm}$ during tumescence [7]. This thinning of the tunica albuginea makes it more susceptible to traumatic injury. Normal pressure in the erect penis is about $100 \mathrm{mmHg}$. When intracavernous pressure exceeds $1500 \mathrm{mmHg}$, a rupture in the tunica albuginea occurs [8]. Penile fracture arising as a result of it is one of the common cases amongst urologic patients admitted to ED. The diagnosis of penile fracture is usually fairly straightforward because of their clinical presentation to ED or urology. Patients with penile fracture generally report a "snapping or cracking" sound, which is followed by pain and rapid penile detumescence. Subsequently swelling, hematoma and penile deformity appears which can be associated with urethral injury.

"False penile fracture" is another urological emergency that is difficult to distinguish from penile fracture. Mostly surgical exploration applies also to "false penile fracture" [1-6]. We believe it is possible to distinguish between these two different penile emergencies without the need for surgical exploration of "false penile fracture".

There is no classic "snapping or cracking" sound in "false penile fracture" and detumescence is not rapid but gradual. Within twenty-four hours after sexual intercourse swelling and mild hematoma on the dorsal side of the penis occurs. Glands penis is normal. There is no sense of fracture on palpation and there is not urethral bleeding due to it is not accompanied by urethral injury.

The above criteria were available in our five patients diagnosed as "false penile fracture" including the two patients with surgical exploration. According to our current opinion, a conservative treatment would have been the accurate treatment for those five patients. We suggest that based on the above clinicopathological features, patients should be considered as "false penile fracture" and treated conservatively (non-steroidal analgesics and ice-packs applications).

On the other hand, the recommended treatment for penile fracture is surgical intervention with closure of the tunica albuginea. The conservative management of penile fracture is not recommended. Complications such as missed urethral disruption, penile curvature, 
persistent hematoma requiring delayed surgical intervention, fibrosis, angulations, and impotence is increased up to $62 \%$ when conservative treatment is used in penile fracture [9-11]. In our study, one out the 2 patients had severe erectile dysfunction.

\section{Limitations}

Follow up period of patients is relatively short. Due to space limitations, we mainly focused on treatment of penile fracture and "false penile fracture" in this study.

\section{CONCLUSIONS}

We believe that distinction between penile fracture and "false penile fracture" is possible with medical history and physical examination. Surgical treatment is needed for the treatment of penile fracture. However, there is no need for surgical exploration for treatment of "false penile fracture". Conservative treatment is sufficient for "false penile fracture".

Declaration of Conflicting Interests: The authors declare that they have no conflict of interest.

Financial Disclosure: No financial support was received.

\section{REFERENCES}

1. Eken A, Acil M, Arpaci T. Isolated rupture of the superficial vein of the penis. Can Urol Assoc J. 2014;8:E371-3.
2. Rafiei A, Hakky TS, Martinez D, et al. Superficial dorsal vein injury/thrombosis presenting as false penile fracture requiring dorsal venous ligation. Sex Med. 2014;2:182-5.

3. Armenakas NA, Hochberg DA, Fracchia JA. Traumatic avulsion of the dorsal penile artery mimicking a penile fracture. J Urol. 2001;166:619.

4. Kurkar A, Elderwy AA, Orabi H. False fracture of the penis: Different pathology but similar clinical presentation and management. Urol Ann. 2014;6:23-6.

5. Feki W, Derouiche A, Belhaj K, et al. False penile fracture: report of 16 cases. Int J Impot Res. 2007;19:471-3.

6. Pereira PA, Fentes PD, Caamaño TV, et al. Rupture of the superficial vein of penis: Therapeutic options. Arch Esp Urol. 2010;63:871-3.

7. Fergany AF, Angermeier KW, Montague DK. Review of Cleveland Clinic experience with penile fracture. Urology. 1999;54:352-5.

8. Cecchi M, Pagni GL, Ippolito C, et al. Fracture of the penis: description of a case. Arch Ital Urol Androl 1997;69:137139.

9. Orvis BR, McAninch JW. Penile rupture. Urol Clin North Am. 1989;16:369-75.

10. Mazaris EM, Livadas K, Chalikopoulos D, et al. Penile fractures: immediate surgical approach with a midline ventral incision. BJU Int. 2009;104:520-3.

11. Savaş A, Efesoy O, Cayan F, Cayan S. Sexual injuries during consensual sexual activity. Ulus Travma Acil Cerrahi Derg. 2012;18:519-23. 